\title{
EPIDEMIOLOGICAL CHARACTERIZATION OF PORCINE TOXOPLASMOSIS IN THE “ALTO SERTÃO” REGION OF SERGIPE, NORTHEASTERN BRAZIL
}

\section{(Caracterização epidemiológica da toxoplasmose suína na região do Alto Sertão do Estado de Sergipe, Brasil)}

José Eduardo Marques Silva ${ }^{1}$, Glenda Lídice de Oliveira Cortez Marinho ${ }^{2}$, Márcia Mariza Gomes Jusi $^{3}$, José Givanildo da Silva ${ }^{4}$, lago Carvalho Barbosa ${ }^{5}$, Sergio Santos Azevedo ${ }^{6}$, Rinaldo Aparecido Mota $^{2}$, Rafael Felipe da Costa Vieira ${ }^{7}$, Danilo Tancler Stipp ${ }^{8}$

${ }^{1}$ Programa de pós-Graduação em Ciência Animal, Universidade Federal da Paraíba; ${ }^{2}$ Departamento de Medicina Veterinária, Universidade Federal Rural de Pernambuco; ${ }^{3}$ Imunodot Diagnósticos;

${ }^{4}$ Programa de Pós-graduação em Biociência Animal, Universidade Federal Rural de Pernambuco;

${ }^{5}$ Programa de Pós-Graduação em Ciência Animal, Universidade Estadual de Londrina; ${ }^{6}$ Centro de

Saúde e Tecnologia Rural, Universidade Federal de Campina Grande; ${ }^{7}$ Departamento de medicina Veterinária, Universidade Federal do Paraná; ${ }^{8}$ Centro de Ciências da Natureza, Universidade Federal de São Carlos

${ }^{1}$ Corresponding author: josesilvamarques@yahoo.com.br

ABSTRACT: Toxoplasma gondii is the etiological agent of toxoplasmosis. Serological studies have demonstrated the parasite occurrence in swine from different regions; however there are no studies that can demonstrate epidemiological status of porcine toxoplasmosis in the Brazilian state of Sergipe. The study purposes were to verify the anti-Toxoplasma gondii antibodies presence and identify risk factors associated with infection in pigs. An amount of 230 blood samples of pigs over four months of age from 45 farms were collected and analyzed by indirect immunofluorescence antibody assay. An epidemiological questionnaire was applied on the properties of origin of the animals to identify risk factors associated with the infection. A seroprevalence of $8.3 \%$ with the titre ranging from $64(15 / 230)$ to 1024 $(02 / 230)$ was found. Animals from the municipalities of Poço Redondo and Canindé de São Francisco showed the highest prevalences, $18.52 \%(5 / 27)$ and $12.90 \%$ (4/31), respectively. The seroprevalence found was considered low when compared to previous studies performed in Brazil, particularly in the northeast region. The age of slaughtered animals should be considered and positive association between the variables age and $T$. gondii infection was found. Most of swine sampled (194/230) were up to six months which may also influence in the seroprevalence. A low anti-T. gondii seroprevalence was observed in the present study, however it is concluded that $T$. gondii infection is present in pigs population. The knowledge about its frequency contributes to the establishment of strategies for disease control by appliance of prevention measures in livestock production.

Keywords: antibodies; epidemiology; RIFI; Toxoplasma gondii.

RESUMO: Toxoplasma gondii é o agente etiológico da toxoplasmose. Estudos sorológicos têm demonstrado a ocorrência do parasita em suínos de diferentes regiões brasileiras; no entanto não há estudos que descrevem a situação epidemiológica da toxoplasmose suína no estado de Sergipe. Os objetivos do estudo foram verificar a presença de anticorpos anti-Toxoplasma gondii e identificar fatores de risco associados à infeção em suínos. Foram coletadas 230 amostras de sangue de suínos com até 4 meses de idade, de 45 propriedades, e analisadas por meio da técnica de imunofluorescência indireta. Foi aplicado questionário 
epidemiológico nas propriedades de origem dos animais para obtenção de dados com o objetivo de identificar fatores de risco associados à infecção. Foi detectada uma soroprevalência de 8,3\% com variação da titulação entre 64 (15/230) e 1024 (02/230). Os municípios de Poço Redondo e Canindé de São Francisco apresentaram as maiores taxas de prevalências, $18,52 \%(5 / 27)$ e 12,90\% (4/31), respectivamente. A soroprevalência determinada foi considerada baixa quando comparada com estudos prévios realizados no Brasil, especialmente na região Nordeste. A idade dos animais abatidos deve ser ponderada, sendo encontrada associação positiva com a infecção por $T$. gondii. A maioria dos animais incluídos no estudo (194/230) apresentavam até seis meses de idade, o que pode ter influenciado na taxa de soroprevalência observada. Foi identificada baixa soroprevalência de anti-T. gondii no estudo, no entanto pôde-se concluir que a infecção por $T$. gondii está presente na população suína. O conhecimento sobre sua epidemiologia pode contribuir na aplicação de estratégias de controle da doença por meio de medidas de prevenção na produção animal.

Keywords: antibodies; epidemiology; RIFI; Toxoplasma gondii. 


\section{INTRODUCTION}

Toxoplasma gondii is the etiological agent of toxoplasmosis, a cosmopolitan anthropozoonosis that affects millions of people in the world. The agent is an intracellular protozoan that can parasitize different tissues types of mammals and birds (Joaquim et al., 2016). Felines, especially domestic cats, are $T$. gondii definitive host, whereas swine, man, reptiles, birds and some invertebrates are intermediate hosts. (Dubey, 2004)

Porcine toxoplasmosis is one of the most important protozoonoses in pig production systems (Dubey, 2004; Joaquim et al., 2016). The animals are infected by consumption of water, food and feed contaminated with oocysts eliminated through cat feces. Bradyzoites develop in muscle and organs tissues, predisposing contamination of products and byproducts intended for human consumption, that leads to abortion, fetal damage and other problems related to public health (Sobestiansky e Barcellos, 2007). T. gondii causes mainly reproductive problems, such as abortion and infertility, likewise reducing production of infected animals, engendering economic losses (Carletti et al., 2005; Andrade et al., 2013; Dabidson, 2004).

In Brazil, serological studies have demonstrated the parasite occurrence in swine from different regions being associated, as risk factors, to breeding type system and technification level (Da Silva, 2000). Previous studies reported the worldwide prevalence of $T$. gondii infection in pigs, where in Brazil it ranges from $1.32 \%$ to $90.4 \%$ (Dubey, 2009a; Dubey, 2009b).

There are no currently studies demonstrating the epidemiological status of porcine toxoplasmosis in the Brazilian State of Sergipe. Therefore, the objectives of the study were to analyze the epidemiological situation of porcine toxoplasmosis in the Alto Sertão region of Sergipe state, and characterize the local epidemiology and risk factors of the disease.

\section{MATERIAL AND METHODS}

The study was conducted in the municipalities that compose the Alto Sertão region of Sergipe, except for the municipalities of Gararu and Nossa Senhora de Lourdes. The Alto Sertão region is composed of seven municipalities: Nossa Senhora da Glória $\left(10^{\circ} 13^{\prime} 06\right.$ "S 3725'13" W); Porto da Folha (09055'02 "S 37016'42" W); Gararu (09-58'03 "S 370.05'00" W); Poço Redondo (09048'18 "S 37041'04" W); Canindé do São Francisco $\left(09^{\circ} 39^{\prime} 36\right.$ "S $37^{\circ} 47^{\prime} 22^{\prime \prime} \mathrm{W}$ ); Monte Alegre de Sergipe $\left(10^{\circ} 01^{\prime} 38\right.$ "S 37033'44" W) and Nossa Senhora de Lourdes $\left(10^{\circ} 04^{\prime} 46\right.$ "S $37^{\circ} 03^{\prime} 28^{\prime \prime} \mathrm{W}$ ) (Figure 1). The length of the territory is $4,900,686 \mathrm{~km}^{2}$, representing $22.37 \%$ of the total state. It has a demographic density of 28hab / $\mathrm{km}^{2}$, which $53.37 \%$ inhabiting the rural area.

Pig farming systems in the municipalities from the Alto Sertão region of Sergipe, as in most of northeast Brazilian area, are characterized by the employment of family members in small farms (IBGE, 2011). The swine producer of this region does not have the pigs as the main source of income, usually as a subsidy for the producer to cross critical periods of drought. The properties located in the study area were visited and investigated through an epidemiological questionnaire, with the consent of the producer. The questionnaire aimed to collect information related to the sanitary aspects of the properties, as facilities cleaning frequency, veterinary assistance, management system type, 
eating habits, cats presence and reproductive problems.

A total of 230 blood samples of pigs over 4 months of age were collected from October to December 2015. The samples were collected using vacuum tubes during the bleeding of the animals slaughtered in the slaughterhouses of the municipalities of Nossa Senhora da Glória and Canindé do São Francisco. The material was identified and packed in icebox. After centrifugation, the serum was stored in identified $1.5 \mathrm{~mL}$ polypropylene microtubes and maintained at $-20{ }^{\circ} \mathrm{C}$.

Swine sera were examined for the presence anti- $T$. gondii antibody through Indirect Immunofluorescence antibody assay (IFA) using $\mathrm{RH}$ sample of $T$. gondii tachyzoites fixed in slides (Camargo, 1974). Anti-IgG-swine antibody (Sigma catalog \#F1638) diluted 1:64 in PBS solution containing Evans blue $1 \mathrm{mg} \%$ was used. Positive samples were submitted to serial dilution at base 2 up to 1024 . Titers higher than or equal to 64 were considered positive (Garcia et al., 1999).

The sample size was calculated performing the formula for random simple samples (Thrusfield, 2004), with an expected prevalence of $50 \%$ and error of $6.5 \%$. The sample size was 227 animals, although for safety and approximation purposes 230 animal blood samples were collected.

Risk factor analysis was conducted in two steps: univariate analysis and multivariate analysis. In the univariate analysis, each independent variable was crossed with the dependent variable. Those that presented $p$ value equal to or above of 0.20 by the Chi-square test (Zar, 1999) were selected for multivariate analysis using multiple logistic regression (Hosmer e Lemeshow, 1989). The level of significance adopted in the multiple analyses was $5 \%$. All analyzes were performed using software SPSS (version 20.0 Windows).

\section{RESULTS}

A total of $19 / 230$ (8.3\%) pigs presented antibodies against $T$. gondii. Animals from the municipalities of Poço Redondo and Canindé de São Francisco showed the highest prevalence, $18.52 \%$ (5/27) and $12.90 \%$ (4/31) respectively. Antibody titers ranged between 64 and 1024, with titer 256 being more common, with a frequency of $15.79 \%$ (6/19) (Table 1). As for the system of creation, all the properties visited breed animals trapped in pigsty or sty.

Table 1 - Titration distribution of antiToxoplasma gondii antibodies ( $\lg$ G) obtained from IFA using sera samples from swine slaughtered in the Alto Sertão region, Sergipe, during October to December 2015.

\begin{tabular}{ccc}
\hline $\begin{array}{c}\text { Antibodies } \\
\text { titration }\end{array}$ & Positives & (\%) \\
\hline 64 & 03 & 15.80 \\
128 & 04 & 21.05 \\
256 & 06 & 31.58 \\
512 & 04 & 21.05 \\
1024 & 02 & 10.52 \\
\hline Total & 19 & 100 \\
\hline
\end{tabular}

Table 2 shows the distribution and risk factors in the univariate analysis. There was a higher frequency of seropositive animals on properties that had cats $(9.4 \%)$, when compared to properties without the presence of cats $(2.6 \%)$, but there was no significant association for this variable. The variables age and type of food storage were selected $(P \leq 0.20)$ in the univariate analysis, but excluded in the multivariate analysis. There were no significant associations between gender, cat presence, abortion, water source, cleaning/disinfection, type of feeding and type of facility with $T$. gondii infection. 
Table 2 - Univariate analysis with variable distribution associated to anti- $T$. gondii antibodies presence in the Alto Sertão region of Sergipe, from October to December 2015.

\begin{tabular}{|c|c|c|c|}
\hline Variable/Category & $\mathrm{N}^{\circ}$ of animals & Positives (\%) & $\mathbf{P}$ \\
\hline \multicolumn{4}{|l|}{ Gender } \\
\hline $\mathrm{M}$ & 127 & $12(9.4)$ & \multirow[t]{2}{*}{0.627} \\
\hline $\mathrm{F}$ & 103 & $7(6.8)$ & \\
\hline \multicolumn{4}{|l|}{ Age } \\
\hline$\leq$ six months & 194 & $19(9.8)$ & \multirow[t]{2}{*}{$0.050^{1}$} \\
\hline$>$ six months & 36 & $0(0)$ & \\
\hline \multicolumn{4}{|l|}{ Cat presence } \\
\hline Yes & 191 & $18(9.4)$ & \multirow[t]{2}{*}{0.211} \\
\hline No & 39 & $1(2.6)$ & \\
\hline \multicolumn{4}{|l|}{ Abortion } \\
\hline Yes & 96 & $8(8.3)$ & \multirow[t]{2}{*}{1.000} \\
\hline No & 54 & $4(7.4)$ & \\
\hline \multicolumn{4}{|l|}{ Water source } \\
\hline Treated & 174 & $15(8.6)$ & \multirow{3}{*}{0.616} \\
\hline Untreated & 40 & $2(5)$ & \\
\hline Treated + untreated & 16 & $2(12.5)$ & \\
\hline \multicolumn{4}{|l|}{ Food storage } \\
\hline Closed & 54 & $1(1.9)$ & \multirow[t]{2}{*}{$0.051^{1}$} \\
\hline Opened & 176 & $18(10.2)$ & \\
\hline \multicolumn{4}{|l|}{ Cleaning/Disinfection } \\
\hline Daily/alternate days & 226 & $18(8)$ & \multirow{2}{*}{0.293} \\
\hline Weekly & 4 & $1(25)$ & \\
\hline \multicolumn{4}{|l|}{ Type of feeding } \\
\hline Concentrate & 25 & $1(4)$ & \multirow{4}{*}{0.378} \\
\hline Concentrate + whey & 148 & $11(7.4)$ & \\
\hline Human food residues + & 57 & $7(12.3)$ & \\
\hline Whey + concentrate & & & \\
\hline \multicolumn{4}{|l|}{ Type of Facility } \\
\hline Pigsty & 167 & $14(8.4)$ & \multirow[t]{3}{*}{0.980} \\
\hline Sty & 23 & $2(8.7)$ & \\
\hline Pigsty + Sty & 40 & $3(7.5)$ & \\
\hline
\end{tabular}

\section{DISCUSSION}

The seroprevalence found in the present study was $8.3 \%$ and considered low when compared to previous studies performed in Brazil, particularly in the northeast region. Even though, the age of slaughtered animals should be considered. The present study showed positive association between the variables age and $T$. gondii infection in the univariate analysis, but it was excluded from the multivariate analysis. Most of swine sampled (194/230) were young (up to six months) which may also influence in the seroprevalence as discussed in previous studies (Dubey et al, 1995; Klun et al., 2011), reporting the increase of the prevalence of porcine toxoplasmosis proportionately to the age group. However, very young animals $(<3$ months) may also present high seroprevalence due to the presence of colostral antibodies (Lopes et al., 2013). The present study is corroborated by two other previous studies conducted in the state of Paraná (Moura et al., 2007) and Pernambuco (Fernandes et al., 2011). In these studies, was observed a positivity of $8.54 \%$ in pigs with mean age of 5.3 months and a prevalence of $9.78 \%$ in animals up to six months, respectively.

All animals studied in this research came from properties whose 
the management system was intensive, possibly contributing to a relatively low prevalence when compared to the study conducted in the southern region of Piauí (Souza et al., 2014). The previous study found $25.5 \%$ positive animals, where pigs breed in an intensive system were less exposed to $T$. gondii $(18.5 \%)$ than those breed in a semi-intensive system $(48,5 \%)$. This fact is also confirmed by another study, which shows pigs breed in complete confinement had 29.2 lower risk of having antibodies against $T$. gondii than those kept in a partial containment system [24]. The access of pigs to the pasture increases the risk of infection due to the high exposure of the animals to the oocysts present in the soil and water (Feitosa et al., 2014; Weigel et al., 1995).

Although the variable food storage was selected in the univariate analysis, it was not set as risk factor, since it was excluded from the multivariate analysis. On the other hand, a study performed in the state of Maranhão showed a significant association with the conditions of food storage and seropositivity in goats by $T$. gondii. From twenty-four stocks considered bad, fourteen were positive for T. gondii (Soares et al., 2010).

Regarding the type of feed offered to the animals, there was no significant association. However, higher seropositivity $(12.3 \%)$ in the pigs consuming foods containing human food residues was seen when compared to those fed exclusively on concentrate $(4 \%)$ or concentrate and whey $(7.4 \%)$. The human food residues offered to the swine often contain undercooked meats or even uncooked contaminated ones, promoting the infection of these animals (Giraldi, 1996). In a study from Paraíba, 190 pig samples from slaughterhouses were analyzed and the seroprevalence of $32 \%$ was found from the animals that were fed with human food residues, being considered a risk factor for parasite infection (Feitosa et al., 2014). In contrast, another study found a higher prevalence of seropositives in feed-fed $(10.8 \%)$ than those who consumed human food residues (5.7\%) (Cavalcanti, 2015).

A previous study, showed that cat presence is the main risk factor associated with $T$. gondii infection, where pigs contract the disease through the ingestion of water, food and feed contaminated with oocysts eliminated through the feces of infected cats (Sobestiansky e Barcellos, 2007). However, in the present study, no significant statistical association $(p>0.2)$ was observed for this variable. The frequencies of positive animals, on properties with and without cat presence, were respectively $9.4 \%$ and $2.6 \%$. There are also other possible forms of transmission, such as tachyzoites present in secretions and excretions of hosts infected by the shared use of drinking fountains and feeders, that would facilitate contamination by ingestion (Vitor et al., 1991).

In males, the frequency of positives was $9.4 \%$ and in females it was $6.8 \%$. There were no statistically significant differences in gender and frequency of anti-T. gondii antibodies ( $P$ $=0.627)$. The data indicates that males and females are equally exposed to the risk of infection (Table 2). However, according to a study, females are considered a risk factor for toxoplasmosis due to hormonal, physiological and management differences (Klun et al., 2011). In contrast, another study says that this behavior is more due to a sampling bias than to a sex-linked susceptibility, where other variables not verified in previous studies, may be the real factors associated (Silva et al., 2010). In another study was found that the higher prevalence of infection in male dogs was 
not really related to the gender, but to the fact that these animals received raw viscera as food, which would be the associated risk factor (Brito et al., 2002).

Regarding the cleaning/ disinfection of the facilities, the frequencies of positive animals on daily/alternate days and weekly cleaning were $8 \%$ and $25 \%$, respectively. However, no significant association was found for this variable with the presence of anti- $T$. gondii antibody. A previous study corroborates, showing that the higher frequency of ovine seropositive happens when the cleaning was performed weekly $(21.4 \%)$, followed by monthly $(18.2 \%)$ and daily (15.7\%) (Pereira et al., 2012).

Concerning the water source, the properties that presented the lower frequency were the ones with untreated water source $(5 \%)$, followed by the treatment $(8.6 \%)$ and both waters $(12.5 \%)$. It should be avoided the access of felines to water reservoirs, due to the possibility of these animals to defecate near to water sources (Dubey, 2004). A previous study reported an association between water source and infection, and found that $34.78 \%(O R=2.39)$ of animals from properties where the water was treated reacted positively to $T$. gondii (Brandão et al., 2009).

For titration, a study conducted with 408 pigs from slaughterhouses in the state of Paraná, found the most frequent titer was 1:64 (74\%) (Millar et al., 2008). This data reveals a chronic infection in the animals (Fernandes et al., 2011). In the present study, the titer 1: $256(31.6 \%)$ was observed as being the most frequent, suggesting a possible acute infection in most seropositive animals.

For all remaining variables, the type of installation and the occurrence of abortion did not reveal a risk factor for the occurrence of antibody against $T$. gondii, but it is important to emphasize the importance and the attention that should be given to all variables analyzed in this study, since they can favor the biological cycle of the parasite.

\section{CONCLUSIONS}

A low seroprevalence of anti- $T$. gondii antibodies was observed in the present study in young swines slaughtered in the Alto Sertão region of Sergipe. However, the results showed that these animals can serve as a source of $T$. gondii infection to humans in the State of Sergipe, Brazil, and witch necessarily needs an appropriate control and prevention actions are necessary.

\section{REFERENCES}

ASSADI-RAD, A.M.; NEW, J.C.; PATTON, S. Risk factors associated with transmission of Toxoplasma gondii to sows kept in different management system in Tennessee. Veterinary Parasitology, v.55, n.4, p.289-297, 1995.

BRANDÃO, V.M.; COSTA, F.B.; SILVA, I.A. et al. Levantamento soroepidemiológico da toxoplasmose em ovinos na ilha de São Luís - MA. Ciência Animal Brasileira, suplemento 1, p. 720-725, 2009.

BRITO, A.F.; SOUZA, L.C.; SILVA, A.V. et al. Epidemiological and serological aspects in canine toxoplasmosis in animals with nervous symptoms. Memórias Do Instituto Oswaldo Cruz, v.97, n.1, p. 31-35, 2002.

CAMARGO, M.E. Introdução às técnicas de imunofluorescência. Revista Brasileira de Patologia Clínica, v.10, p.143-169, 1974.

CARLETTI, R.T.; FREIRE, R.L.; SHIMADA, M.T. et al. Prevalência da infecção por Toxoplasma gondii em suínos abatidos no Estado do Paraná, 
Brasil. Semina: Ciências Agrárias, v.26, n.4, p.563, 2005.

CLEMENTINO ANDRADE, M.M.; PINHEIRO, B.V.; CUNHA, M.M. et al. New gentotypes of Toxoplasma gondii obtained from farm animals in Northeast Brazil. Research in Veterinary Science, v.94, n.3, p.587-589, 2013.

DA SILVA, A. V. Ocorrência de anticorpos anti-Toxoplasma gondii em suínos da região oeste do Paraná, Brasil. Revista Veterinária e Zootecnia, v.15, n.1, p.263-266, 2008.DAVIDSON, M.G. Toxoplasmosis. Veterinary Clinics of North America: Small Animal Practice, v.30, n.5, p.1051-1062, 2000.

DUBEY, J.P. Toxoplasmosis in sheep The last 20 years. Veterinary Parasitology, v.163, n.1-2, p.1-14, 2009a.

DUBEY, J.P. Toxoplasmosis - a waterborne zoonosis. Veterinary Parasitology, v.126, n.1-2, p.57-72, 2004.

DUBEY, J.P.; WEIGEL, R.M.; SIEGEL, A.M. et al. Sources and reservoirs of Toxoplasma gondii infection on 47 swine farms in Illinois. The Journal of Parasitology, v.81, n.5., p.723-9, 1995.

DUBEY, J.P. Toxoplasmosis of animals and humans. New York, CRC Press, 2009b. 336 p.

FEITOSA, T.F.; VILELA, V.L.R.; BEZERRA DE MELO, L.R. et al. Toxoplasma gondii and Neospora caninum in slaughtered pigs from Northeast, Brazil. Veterinary Parasitology, v.202, n.3-4, p. 305-309, 2014.

FERNANDES, E.F.T.S.; SIMÕES, S.G.; FARIA, E. et al. Anticorpos IgG antiToxoplasma gondii em suínos abatidos em matadouros da região metropolitana do Recife, Pernambuco, Brasil.
Arquivos Do Instituto Biológico, v.78, n.3, p.425-428, 2011.

GARCIA, J.L.; NAVARRO, I.T.; OGAWA, L. et al. Soroepidemiologia da toxoplasmose e avaliação ocular pela Tela de Amsler, em pacientes da zona rural, atendidos na unidade de saúde do município de Jaguapitã, PR, Brasil. Revista Da Sociedade Brasileira de Medicina Tropical, v.32, n.6, p.671676, 1999.

GIRALDI, N. Estudo da toxoplasmose congênita natural em granjas de suínos em Londrina, PR. Arquivo Brasileiro de Medicina Veterinária e Zootecnia, v.48, n.1, p. 83-90, 1996.

HOSMER, D.W.; LEMESHOW, S. Applied logistic regression, New York, Wiley, 1989. 375 p.

IBGE - Instituto Brasileiro de Geografia e Estatística. "Produção Pecuária Municipal", 2011. <ftp://ftp.ibge.gov.br/Producao_Pecuaria /Producao_da_Pecuaria_Municipal/ 2011/ (12/05/2015)>.

JOAQUIM, S.F.; LATOSINSKI, G.S.; DIAS, N.M. et al. Zoonoses em animais de produção: Aspectos gerais. Revista Veterinária e Zootecnia, v.23, n.1, p.49-71, 2016.

KLUN, I.; VUJANIĆ, M.; YERA, H. et al. Toxoplasma gondii infection in slaughter pigs in Serbia: seroprevalence and demonstration of parasites in blood. Veterinary Research, v.42, n.1, p.17, 2011.

LOPES, A.P.; DUBEY, J.P.; NETO, F. et al. Seroprevalence of Toxoplasma gondii infection in cattle, sheep, goats and pigs from the North of Portugal for human consumption. Veterinary Parasitology, v.193, n.1-3, p.266-269, 2013.

MILLAR, P.R.; DAGUER, H.; VICENTE, R.T. et al. Toxoplasma gondii: estudo soro-epidemiológico de suínos da região 
Sudoeste do Estado do Paraná.

Pesquisa Veterinária Brasileira, v.28, n.1, p. 15-18, 2008.

MOURA, A.B.; DE, S.C.; OSAKI, D.L. et al. Ocorrência de anticorpos contra Toxoplasma gondii em suínos e ovinos abatidos no município de Guarapuava, PR, Brasil. Revista Brasileira de Parasitologia, v.16, n.1, p54-56, 2007.

PEREIRA, M.F.; PEIXOTO, R.M.; LANGONI, $H$. et al. Fatores de risco associados à infecção por Toxoplasma gondii em ovinos e caprinos no estado de Pernambuco. Pesquisa Veterinária Brasileira, v.32, n.2, p. 140-146, 2012.

SILVA, A.V.; $\quad$ SILVA, R.C.; ZAMPROGNA, T.O. et al. Toxoplasma gondii em suínos com ênfase na contribuição brasileira. Scientia Medica, v.20, n.1, p. 120-130, 2010.

SOARES, J.G.; SILVA, M.I.S.; BRANDÃO, V.M. Frequência de anticorpos anti-Toxoplasma gondii em rebanhos caprinos do município de São Luís, MA. Ciência Animal Brasileira, v.11, n.3, p. 660-668, 2010.

SOBESTIANSKY, J.; BARCELLOS, D. Doenças dos suínos. Goiânia, Canone Editorial, 2007. 768 p.

SOUSA, R.Á.; LEMOS, J.F.; Farias, L.A. et al. Seroprevalence and risk factors for Toxoplasma gondii infection in pigs in southern Piauí. Revista Brasileira de Parasitologia Veterinária, v.23, n.1, p.98-100, 2014.

THRUSFIELD, M. Epidemiologia Veterinária, São Paulo, Roca, 2004. $556 \mathrm{p}$.

ZAR, J.H. Biostatistical analysis. New Jersey, Upper Saddle River, 1999. 663

p.

VITOR, R.W.A.O.; PINTO, J.B.; CHIARI, C.A. Eliminação de Toxoplasma gondii através de urina, saliva e leite de caprinos experimentalmente infectados.

Arquivo Brasileiro de Medicina
Veterinária e Zootecnia, v.43, n.2, p. 147-154, 1991.

WEIGEL, R.M.; DUBEY, J.P.; SIEGEL, A.M. et al. Risk Factors for Transmission of Toxoplasma gondii on Swine Farms in Illinois. The Journal of Parasitology, v.81, n.5, p.736-741, 1995. 